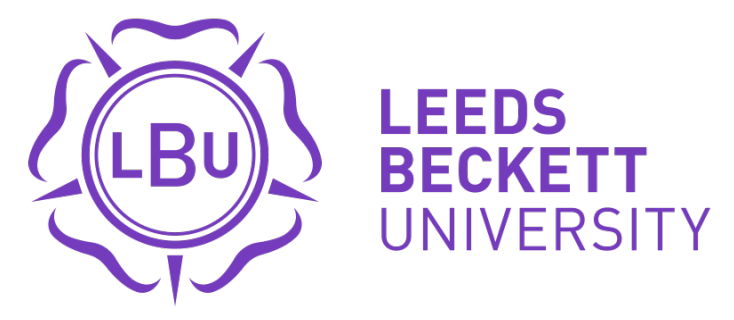

Citation:

Tashani, OA and Eltumi, H and Aneiba, K (2016) Pain Outcomes in Patients after Artificial Disc Replacement versus Fusion in the Cervical Spine: A Systematic Review of Systematic Reviews. Journal of Spine and Neurosurgery, 5 (6). ISSN 2325-9701 DOI: https://doi.org/10.4172/23259701.1000237

Link to Leeds Beckett Repository record:

https://eprints.leedsbeckett.ac.uk/id/eprint/3796/

Document Version:

Article (Published Version)

Creative Commons: Attribution 4.0

The aim of the Leeds Beckett Repository is to provide open access to our research, as required by funder policies and permitted by publishers and copyright law.

The Leeds Beckett repository holds a wide range of publications, each of which has been checked for copyright and the relevant embargo period has been applied by the Research Services team.

We operate on a standard take-down policy. If you are the author or publisher of an output and you would like it removed from the repository, please contact us and we will investigate on a case-by-case basis.

Each thesis in the repository has been cleared where necessary by the author for third party copyright. If you would like a thesis to be removed from the repository or believe there is an issue with copyright, please contact us on openaccess@leedsbeckett.ac.uk and we will investigate on a case-by-case basis. 


\section{Pain Outcomes in Patients after Artificial Disc Replacement versus Fusion in the Cervical Spine: A Systematic Review of Systematic Reviews \\ Tashani OA ${ }^{1 *}$, EL-Tumi HG ${ }^{2}$ and Aneiba $\mathbf{K}^{1,2}$}

\begin{abstract}
Background: Pain is a major complaint for patients with cervical disc disease and is one of the reasons for surgery. Cervical artificial disc replacement (C-ADR) has been introduced in 2002 to offer an alternative to anterior cervical discectomy and fusion (ACDF) to treat disc disease in the cervical spine and to reduce dysphagia, dislodgement or fracture in the affected segment or an increase motion at the adjacent levels of the cervical spine. Several studies and reviews attempted in the last decade to compare the two procedures head to head and to evaluate whether the new procedure lead to less complications, better clinical outcomes and more patients' satisfaction. However, less attention was paid to pain outcomes in these studies.
\end{abstract}

Aim: To evaluate the pain outcomes resulted from C-ADR in comparison to ACDF by reviewing the evidence presented in the systematic reviews of randomized clinical trails and other studies containing clinical data.

Methods: A combination of the following keywords was used in the search for systematic reviews in [Medline via Ovid, Embase, Cochrane Database of Systematic Reviews, Google scholar]: (total disc replacement, prosthesis, implantation, diskectomy, arthroplasty) and (cervical vertebrae, cervical spine, spine) and (pain, disability, quality of life) and (systematic reviews, reviews, meta-analysis). The initial search was conducted on the 18 August 2013 and then updated on 02/12/2015. Two authors screened the results of the search independently. For the article to be selected for further consideration it has to be a systematic review and/or meta-analysis of trials that attempted to compare between the two interventions at the cervical region in which the pain relief was a primary or a secondary outcome.

Results: The electronic search produced 881 hits of which 145 were duplicates. Twenty more articles were identified through manual search. Initial screening of the abstracts resulted in selection of 68 articles for further evaluation. The final judgement of the two reviewers was to include 10 systematic reviews and/or metaanalyses in this overview. The number of randomised trials reviewed by the selected reviews varies from 2 to 27 . Other discrepancies

*Corresponding author: Dr. Osama Tashani, Senior Research Fellow, Faculty of Health and Social Sciences, Leeds Beckett University, Portland PD609, City Campus, Leeds LS1 3HE, United Kingdom, Tel: +44 (0)113 812 3858; E-mail: O.Tashani@leedsbeckett.ac.uk

Received: April 19, 2016 Accepted: June 14, 2016 Published: June 20 2016 between the reviews included: the follow up period, the outcomes considered and reporting of heterogeneity or publication bias of the included studies. Eight reviews and meta-analyses concluded that overall C-ADR is more effective and probably superior to ACDF specifically in neurological success, low rate of secondary operation and most pain outcomes. One meta-analysis concluded that ACDF is associated with shorter operative time and less blood loss compared to C-ADR. However, a Cochrane review critically evaluated the differences between the clinical outcomes of the two interventions and while confirmed that C-ADR superiority may be statistically significant in many of these outcomes, the differences between C-ADR and ACDF is too small. This was also evident in all meta-analyses evaluated here.

Conclusion: C-ADF may be superior, or at least equivalent, to ACDF in most clinical and patients' outcomes but the effect size of the difference is small and more time and research is needed to reach a definitive conclusion. A robust systematic reviewing is also recommended.

\section{Keywords}

Pain; Cervical spine; Artrhoplasty; Fusion

\section{Introduction}

Cervical artificial disc replacement (C-ADR), or as sometimes referred to as Cervical Disc Arthroplasty (CDA), was introduced in 2002 to offer an alternative to anterior cervical discectomy and fusion (ACDF) to treat disc disease in the cervical spine. It is claimed that $\mathrm{C}$-ADR reduces dysphagia, dislodgement or fracture in the affected segment and increases motion at the adjacent levels of the cervical spine. In the last decade there have been several studies that have evaluated whether C-ADR leads to fewer complications, better in multi-level clinical outcomes and more patients' satisfaction than ACDF. Little attention has been paid to pain outcomes in systematic reviews of these studies despite the fact that cervical degenerative disc disease results in significant pain and disability [1]

Cervical disease prevalence increased with aging and as a consequence to chemical and structural changes in the disc. These changes lead to neck and arm pain which is usually associated with radiculopathy and myelopathy [1]. The radiculopathy is a neurological condition caused by the compression or irritation of the spinal nerves when they exit the spine. In this condition there is a dysfunction of the cervical spinal nerve, the root of the nerve, or both. It may cause some symptoms along the course of the nerve like pain numbness, tingling, or weakness. Commonly, the patient present with neck and arm pain, a combination of sensory loss, motor function loss, or reflex changes in the affected nerve distribution [2]. Whereas, the myelopathy refers to any neurological insufficiency connected to the spinal cord. It is generally caused by an increased number of osteophytes or extruded disc material in the cervical spine [3]. The most frequent cause of cervical radiculopathy and myelopathy in the elderly is cervical spondylosis which is a common pathological condition affecting adult spine [4]. The condition can be assessed through neurological examinations such as testing for loss of feeling, reflexes and muscle strength and confirmed by MRI and other imaging technology.

For all the cervical disc disease condition pain is a common complaint for patients and is one of the conditions for surgery. It 
is common practice that the cervical degenerative disc disease is treated with conservative treatment before attempting any invasive intervention. Timing of deciding a surgical intervention varies according to the improvement in the response to conservative treatment or the severity of the symptoms. It was suggested that if after 2-6 months of conservative treatment there was no improvement and pain affected the daily activities and life quality of a patient, then the surgical interventions may be considered [5]. Traditionally, it has been considered that artificial cervical discectomy and fusion (ACDF) is the standard surgical treatment for cervical degenerative disc disease that results in pain, instability, radiculopathy, and myelopathy [6]. During ACDF procedure, incision is made in the front of the neck and the degenerated disc is removed then the space is filled with piece of bone graft ( from a cadaver or patient's pelvis) or synthetic (titanium or medical grade plastic) cage device in order to stimulate the fusion between vertebral endplates. This procedure aim to promote a bony bridge between the two vertebrae by interposition of cage, by either autograft or allograft bone placed in the intervertebral space, by plate and screw fixation, or by a mixture of these [7]. This procedures presented surgeons and patients alike with challenges of kinematic nature in the cervical spine.

More recently, to preserve the kinematics of functional spinal joints an alternative surgical procedure, total cervical disc replacement (C-ADR), has replaced ACDF in cervical degenerative disc disease patients. This procedure is similar to cervical discectomy and fusion except that there is an implantation of disc replacement device in the gap between the two vertebral bodies [7], which is characteristically composed of two metal surfaces one surface edge attached to the upper vertebrae and the other surface attached to the lower vertebrae at the same level. With this device the motion between two vertebrae is maintained and then the need of fusion can be avoided. There is a need to evaluate the evidence of success of this surgical procedure in reducing pain.

Therefore the aim of this study was to evaluate effect of C-ADR compared with ACDF on pain outcomes by reviewing evidence presented in systematic reviews of randomized clinical trials and studies containing clinical data.

\section{Methods}

Combinations of keywords were used to search for systematic reviews in Medline via Ovid, Embase, Cochrane Library, and Google scholar including: (total disc replacement, prosthesis, implantation, discectomy, arthroplasty) AND (cervical vertebrae, cervical spine, spine) AND (pain, disability, quality of life) AND (systematic reviews, reviews, meta-analysis). The initial search was conducted on 18 August 2013 and updated on 02 December 2015. Eligibility criteria were: systematic review and/or meta-analysis of randomised controlled trials (RCTs) that compared C-ADR with ACDF at the cervical region with pain being a primary or a secondary outcome. Screening of articles identified in the search was conducted by two authors (OAT, KA) independently. Quality of the reviews was assessed using AMSTAR tool [8] for systematic reviews by two authors (OAT, HET). The data on pain and other clinical outcomes were extracted by two authors independently (OAT, HGET) and the third author worked as an arbiter in any dispute. Data was then tabulated and effectiveness of the intervention compared was judged using the GRADE system on pain outcomes [9]. If authors of the systematic reviews reported on the effectiveness of the outcomes using the GRADE then their judgement was cross-checked against the studies they have selected. In cases were the outcomes were not evaluated two authors evaluated the quality of evidence using the GRADE system as described by [9].

\section{Results}

The initial search produced 881 citations of which 145 were duplicates (Figure 1). Screening of full reports of 68 relevant abstracts resulted in 10 systematic reviews and/or meta-analyses selected for this overview. The systematic reviews selected contained analysis of a range of 2 to 27 RCTs per review. However, the quality of many of these RCTs is questionable. Anderson et al. [10] and Yang et al. [4] failed to report pain outcomes and RCT reviewed by Bartels et al. [11] and Gao et al. [12] lack data on description of randomisation processes or allocation concealment which affected the overall quality of evidence. There were discrepancies in the analysis of RCTs studies between the systematic reviews in the length of the follow up period, the outcomes considered and reporting of heterogeneity and publication bias.

Eight reviews provided evidence that C-ADR reduced pain in arms and the neck measured by numerical rating or visual analogue scales at 1 to 2 years follow-up, although none of the RCTs described how pain was managed. A Cochrane review found significant superiority of efficacy of C-ADR compared with ACDF in many outcomes, including pain, but the effect size was too small. Table 1 describes the characteristics of the reviews including the reported outcomes, quality assessment and quality of evidence.

Most of the reviews $(n=7)$ were on single level, based the conclusion on single level or contains the majority of studies on single levels. Therefore, most of the conclusion in this review will be valid for single level disc disease and should be approached with caution for multi-level disease. Few studies, which attempted comparing single and multi-level outcomes, reported that improvement in pain VAS scores for both the arm and the neck were slightly better in multi-level than in single level patients [13]. However, most studies included both single level and multi-level patients reported no differences overall.

As for adjacent level secondary degeneration there is no evidence that there are differences between the two surgical interventions examined here. However, one systematic review which was focusing on this particular outcome suggested that adjacent level secondary degeneration may occur more commonly in ACDF than with total disc replacement [14].

There was little information in the systematic reviews selected here to enable us to comment on the failure rate of C-ADR in terms of infections or implant removal. However, there was some consensus as $\mathrm{C}-\mathrm{ADR}$ offers numerous potential advantages including a rapid postoperative recovery [15]. However, a systematic review on cervical artificial disc replacement wear characteristics and durability concluded that cervical disc implants consistently produced polymeric and metallic debris, which was typically accompanied by inflammation. It should be also acknowledged that hypersensitivity to metal of the artificial disc may increase risk for device failure [16].

\section{Discussion}

Our findings from the reviewed systematic reviews regarding pain outcomes is that for both arm and neck pain C-ADR is significantly more effective than ACDF in reducing pain after one year follow up but the difference effect size is small and quality of evidence is low to intermediate in 7 and very low in two systematic reviews. It was not possible to judge the evidence in one systematic review due to missing information [17]. In GRADE system a low quality grade of evidence 
Citation: Tashani OA, EL-Tumi HG, Aneiba K (2016) Pain Outcomes in Patients after Artificial Disc Replacement versus Fusion in the Cervical Spine: A Systematic Review of Systematic Reviews. J Spine Neurosurg 5:5.
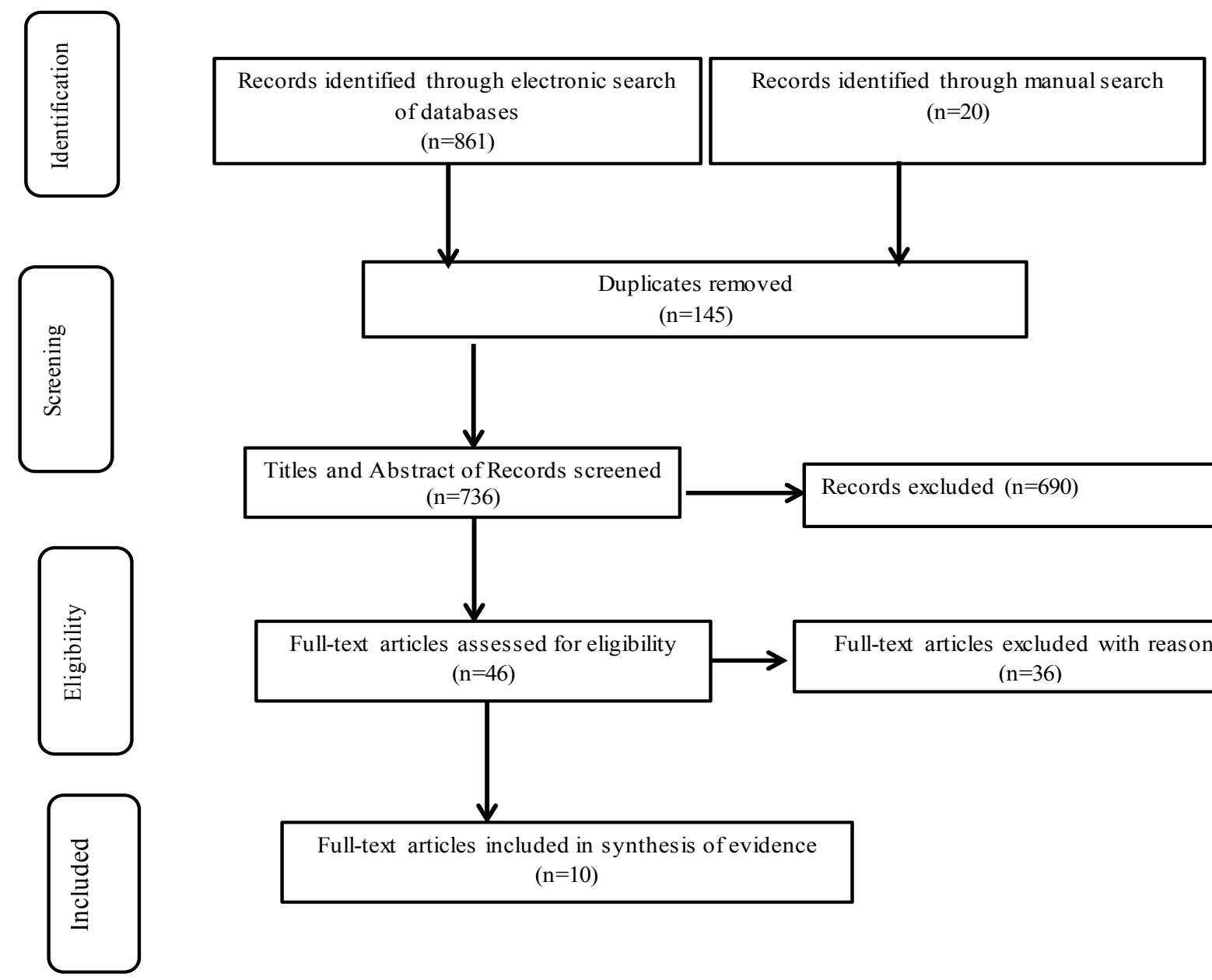

Figure 1: Prisma flow chart to identify eligible studies.

Table 1: Characteristics of included systematic reviews and meta-analysis.

\begin{tabular}{|c|c|c|c|c|c|c|c|c|c|c|c|c|c|}
\hline $\begin{array}{l}\text { Systematic } \\
\text { Review }\end{array}$ & $\begin{array}{l}\text { Studies } \\
\text { included } \\
\text { (N) }\end{array}$ & $\begin{array}{l}\text { Follow } \\
\text { up } \\
\text { period } \\
\text { (Years) }\end{array}$ & $\begin{array}{l}\text { Patients } \\
\text { (N) }\end{array}$ & level & $\begin{array}{l}\text { Arm } \\
\text { Pain }\end{array}$ & Neck Pain & $\begin{array}{l}\text { Neck } \\
\text { Related } \\
\text { function } \\
\text { status }\end{array}$ & $\begin{array}{l}\text { Patient } \\
\text { satisfaction }\end{array}$ & $\begin{array}{l}\text { Neurological } \\
\text { status }\end{array}$ & $\begin{array}{l}\text { Global } \\
\text { Health } \\
\text { status } \\
\text { SF36 }\end{array}$ & $\begin{array}{l}\text { Other surgical } \\
\text { outcomes }\end{array}$ & $\begin{array}{l}\text { Quality } \\
\text { assessment }\end{array}$ & $\begin{array}{l}\text { Quality of } \\
\text { evidence } \\
\text { (overall) }\end{array}$ \\
\hline $\begin{array}{l}\text { Anderson et } \\
\text { al. } 2012(10)\end{array}$ & $\begin{array}{l}12 \\
7 \text { RCT } \\
4 \text { Cohort } \\
\text { I CC }\end{array}$ & $1-2$ & 1122 & Single-level & NR & NR & NR & NR & NR & FA & $\begin{array}{l}\text { 1-Adjacent } \\
\text { segment ROM: } \\
\text { No difference } \\
\text { 2-changes } \\
\text { in sagittal } \\
\text { alignment at the } \\
\text { cranial and the } \\
\text { caudal adjacent } \\
\text { segment from } \\
\text { baseline was } \\
\text { more lordotic } \\
\text { after arthroplasty }\end{array}$ & 6 & $\begin{array}{l}\text { Low to } \\
\text { moderate for } \\
\text { most outcomes, } \\
\text { High for Caudal } \\
\text { adjacent } \\
\text { segment sagittal } \\
\text { alignment }\end{array}$ \\
\hline $\begin{array}{l}\text { Bartels et al. } \\
2010 \text { (11) }\end{array}$ & $10 \mathrm{RCT}$ & $1-2$ & 1533 & Single-level & $\begin{array}{l}\text { VAS : } \\
1 \text { year } \\
\text { FA, } \\
2 \\
\text { years } \\
\text { ND }\end{array}$ & $\begin{array}{l}\text { VAS : } \\
1 \text { year FA, } \\
2 \text { years ND }\end{array}$ & NDI: FA & NR & NR & $\begin{array}{l}1 \text { year } \\
\text { FA, } \\
2 \text { years } \\
\text { ND }\end{array}$ & $\begin{array}{l}\text { Secondary } \\
\text { surgeries } \\
\text { for adjacent } \\
\text { segment } \\
\text { disease: no } \\
\text { difference. }\end{array}$ & 9 & $\begin{array}{l}\text { Not evaluated by } \\
\text { authors. } \\
\text { Intermediate } \\
\text { due to unclear } \\
\text { allocation } \\
\text { concealment in } 5 \\
\text { studies. }\end{array}$ \\
\hline $\begin{array}{l}\text { Boselie et al } \\
2012(7)\end{array}$ & $9 \mathrm{RCT}$ & $1-2$ & 2400 & Single level & FA & FA & FA & ND & FA & FA & & 11 & $\begin{array}{l}\text { Low to } \\
\text { moderate for } \\
\text { all outcomes } \\
\text { except patient } \\
\text { satisfaction } \\
\text { which was very } \\
\text { low }\end{array}$ \\
\hline
\end{tabular}


Citation: Tashani OA, EL-Tumi HG, Aneiba K (2016) Pain Outcomes in Patients after Artificial Disc Replacement versus Fusion in the Cervical Spine: A Systematic Review of Systematic Reviews. J Spine Neurosurg 5:5.

doi: $10.4172 / 2325-9701.1000237$

\begin{tabular}{|c|c|c|c|c|c|c|c|c|c|c|c|c|c|}
\hline $\begin{array}{l}\text { Gao et al. } \\
2013(12)\end{array}$ & $27 \mathrm{RCT}$ & $\begin{array}{l}\text { Short- } \\
\text { term but } \\
\text { period } \\
\text { was not } \\
\text { reported }\end{array}$ & $\mathrm{NR}^{*}$ & $\begin{array}{l}\text { Studies } \\
\text { selected } \\
\text { were on } \\
\text { single } \\
\text { level or the } \\
\text { number } \\
\text { of levels } \\
\text { were not } \\
\text { reported. }\end{array}$ & FA & FA & NDI: ND & & FA & NR & $\begin{array}{l}\text { More Blood loss, } \\
\text { longer operative } \\
\text { time, and fewer } \\
\text { secondary } \\
\text { surgical } \\
\text { procedure in } \\
\text { the arthroplasty } \\
\text { group. Greater } \\
\text { motion at the } \\
\text { operated level } \\
\text { FA }\end{array}$ & 7 & $\begin{array}{l}\text { Low, data on } \\
\text { randomisation, } \\
\text { concealment of } \\
\text { allocations and } \\
\text { other limitations } \\
\text { were not } \\
\text { available. }\end{array}$ \\
\hline $\begin{array}{l}\text { Gebremariam } \\
\text { et al. } 2012 \\
\text { (18) }\end{array}$ & $3 \mathrm{RCT}$ & $1-2$ & 169 & $\begin{array}{l}\text { Studies } \\
\text { selected } \\
\text { were on } \\
\text { single } \\
\text { level or the } \\
\text { number } \\
\text { of levels } \\
\text { were not } \\
\text { reported. }\end{array}$ & NR & ND & NR & NR & NR & & $\begin{array}{l}\text { Clinical status } \\
\text { favours ACDF }\end{array}$ & 7 & $\begin{array}{l}\text { Very low for all } \\
\text { outcomes }\end{array}$ \\
\hline $\begin{array}{l}\text { Cepoiu- } \\
\text { Martin et al. } \\
2011 \text { (13) }\end{array}$ & $\begin{array}{l}18 \\
13 \text { case } \\
\text { series } \\
4 \mathrm{RCT} \\
1 \text { non } \\
\text { randomized } \\
\text { comparative } \\
\text { stud }\end{array}$ & 1-2 & 1108 & $\begin{array}{l}\text { Single and } \\
\text { multi-level }\end{array}$ & FA & FA & ND & ND & $=$ & NR & $\begin{array}{l}\text { Preservation } \\
\text { of spine } \\
\text { mobility favours } \\
\text { arthroplasty }\end{array}$ & 7 & $\begin{array}{l}\text { Very low for all } \\
\text { outcomes }\end{array}$ \\
\hline $\begin{array}{l}\text { Yang et } \\
\text { al.2012 (4) }\end{array}$ & $5 \mathrm{RCT}$ & $2-5$ & 1413 & $\begin{array}{l}4 \text { studies } \\
\text { were one } \\
\text { level. } \\
1 \text { study }(71 \\
\text { patient one } \\
\text { level and } 22 \\
\text { patients } 2 \\
\text { levels) }\end{array}$ & NR & NR & NR & NR & NR & NR & $\begin{array}{l}\text { No statistical } \\
\text { significance } \\
\text { between the two } \\
\text { interventions } \\
\text { in occurrence } \\
\text { of adjacent } \\
\text { segment } \\
\text { degeneration }\end{array}$ & 9 & $\begin{array}{l}\text { Low for all } \\
\text { outcomes }\end{array}$ \\
\hline $\begin{array}{l}\text { Yin et al } 2013 \\
\text { (19) }\end{array}$ & $\begin{array}{l}13 \\
10 \mathrm{RCT} \\
\text { included in } \\
\text { the meta- } \\
\text { analysis }\end{array}$ & $1-5$ & 2227 & $\begin{array}{l}13 \text { studies } \\
\text { were single } \\
\text { level. } \\
1 \text { study was } \\
1,2, \text { or } 3 \\
\text { levels }\end{array}$ & $\begin{array}{l}\text { NRS } \\
\text { FA }\end{array}$ & NRS FA & NDI:ND & NR & FA & $\begin{array}{l}\text { SF-36 } \\
\text { PCS } \\
\text { FA }\end{array}$ & $\begin{array}{l}\text { Adjacent } \\
\text { segment: no } \\
\text { difference(very } \\
\text { low) }\end{array}$ & 7 & $\begin{array}{l}\text { Moderate for } \\
\text { all outcomes } \\
\text { EXCEPT } \\
\text { adjacent } \\
\text { segment } \\
\text { degeneration } \\
\text { which is very low }\end{array}$ \\
\hline $\begin{array}{l}\text { Yu. Et. Al. } \\
2011 \text { (17) }\end{array}$ & $8 \mathrm{RCT}$ & 2 & 1004 & $\begin{array}{l}\text { Conclusion } \\
\text { was based } \\
\text { on single } \\
\text { level } \\
\text { studies }\end{array}$ & $\begin{array}{l}\text { VAS } \\
\text { ND }\end{array}$ & VAS FA & NDI:ND & FA & NR & $\begin{array}{l}\text { Overall } \\
\text { success } \\
\text { rate: } \\
\text { FA }\end{array}$ & $\begin{array}{l}\text { Overall } \\
\text { reoperation rate } \\
\text { and } \\
\text { Reoperation } \\
\text { rate for revision: } \\
\text { favours } \\
\text { arthroplasty }\end{array}$ & 7 & $\begin{array}{l}\text { Not clear due } \\
\text { to missing } \\
\text { information }\end{array}$ \\
\hline $\begin{array}{l}\text { Zechmeister } \\
\text { et al } 2010 \\
(20)\end{array}$ & 7 RCT & $1-2$ & 2298 & $\begin{array}{l}6 \text { studies } \\
\text { were single } \\
\text { level } \\
1 \text { study was } \\
\text { two level }\end{array}$ & $\begin{array}{l}5 \mathrm{RCT} \\
\mathrm{ND} \\
1 \mathrm{RCT} \\
\mathrm{FA}\end{array}$ & $\begin{array}{l}\text { NR in } 3 \\
\text { RCT } \\
2 \text { RCT } \\
\text { favours } \\
\text { arthroplasty }\end{array}$ & $\begin{array}{l}\text { NDI: } \\
\text { FA in } 2 \\
\text { RCT }\end{array}$ & ND & $\begin{array}{l}3 \mathrm{RCT} \\
\text { favours } \\
\text { arthroplasty }\end{array}$ & $\begin{array}{l}1 \mathrm{RCT} \\
\mathrm{FA}\end{array}$ & $\begin{array}{l}\text { No differences } \\
\text { overall in most } \\
\text { other outcomes }\end{array}$ & 6 & $\begin{array}{l}\text { Moderate for all } \\
\text { outcomes }\end{array}$ \\
\hline
\end{tabular}

VAS=Visual Analogue Scale; NRS=Numerical Rating Scale; NDI=Neck Disability Index; PCS=Physical Health Survey; MCS=Mental Health Survey; ACDF=Anterior Cervical Discectomy and Fusion; NR=Not Reported; RCT=Randomized Controlled Trail; CC=Case Series. FA=Favours C-ADR

* Total $\mathrm{N}$ was not reported. $\mathrm{N}$ for each outcome in this meta-analysis ranged from 248 to 656

mean that further research is very likely to have an important impact on our confidence in the estimate of effect and is likely to change the estimate while very low quality grade means uncertainty about the estimate. Therefore it is essential to acknowledge that as far as pain outcomes in cervical spine patients is concerned a further research is needed to increase our confidence in the conclusion that C-ADR is more effective in reducing pain after a one year follow up. However, it was apparent from this overview that the choice of the surgery type is a result of many factors in which pain outcome is probably not considered because the differences between the two surgical interventions in reducing pain is very small and of less consequence on choice of surgery type.

While most studies reviewed in the 10 systematic reviews were RCT in nature randomisation and concealment of allocation remained a challenge in studies of surgical interventions because of the many factors affecting choice and delivery of surgery. Another major limitation was the failure of the studies included to document the treatment of pain postoperatively. We recommend that this information have to be included in further RCT or other studies aiming to evaluate the differences between surgical interventions [18-20].

\section{Conclusion}

C-ADF may be more effective to ACDF in controlling pain in cervical patients after 1 to 2 years of surgery but the effect size of the difference is small to be clinically meaningful.

\section{Conflict of Interest}

This research was financially supported by MBA, Trimedica Ltd and Alphatec Spine. The sponsors had no role in the study, decision to publish or any copyright relevant to the study.

\section{References}

1. Todd AG (2011) Cervical spine: degenerative conditions. Curr Rev Musculoskelet Med 4: 168-174. 
Citation: Tashani OA, EL-Tumi HG, Aneiba K (2016) Pain Outcomes in Patients after Artificial Disc Replacement versus Fusion in the Cervical Spine: A Systematic Review of Systematic Reviews. J Spine Neurosurg 5:5.

2. Carette S, Fehlings MG (2005) Clinical practice. Cervical radiculopathy. N Engl J Med 353: 392-399.

3. Seidenwurm DJ; Expert Panel on Neurologic Imaging (2008) Myelopathy AJNR Am J Neuroradiol 29: 1032-1034.

4. Yang B, Li H, Zhang T, He X, Xu S (2012) The incidence of adjacent segment degeneration after cervical disc arthroplasty (CDA): a meta analysis of randomized controlled trials. PLoS One 7: e35032.

5. Gallucci M, Limbucci N, Paonessa A, Splendiani A (2007) Degenerative disease of the spine. Neuroimaging Clin N Am 17: 87-103.

6. Verma K, Gandhi SD, Maltenfort M, Albert TJ, Hilibrand AS, et al. (2013) Rate of adjacent segment disease in cervical disc arthroplasty versus single-leve fusion: Meta-analysis of prospective studies. Spine 38: 2253-2257.

7. Boselie TF, Willems PC, van Mameren H, de Bie RA, Benzel EC, et al. (2012) Arthroplasty versus fusion in single-level cervical degenerative disc disease: A Cochrane review. Spine 38: E1096-E1097.

8. Shea BJ, Grimshaw JM, Wells GA, Boers M, Andersson N, et al. (2007) Development of AMSTAR: A measurement tool to assess the methodological quality of systematic reviews. BMC Med Res Methodol 7: 10.

9. Guyatt GH, Oxman AD, Vist G, Kunz R, Brozek J, et al. (2011) GRADE guidelines: 4 . Rating the quality of evidence--study limitations (risk of bias). J Clin Epidemiol 64: 407-415.

10. Anderson PA, Sasso RC, Hipp J, Norvell DC, Raich A, et al. (2012) Kinematics of the cervical adjacent segments after disc arthroplasty compared with anterior discectomy and fusion: A systematic review and meta-analysis. Spine 37: S85-S95

11. Bartels RH, Donk R, Verbeek AL (2010) No justification for cervical disk prostheses in clinical practice: a meta-analysis of randomized controlled trials. Neurosurgery 66: 1153-1160.
12. Gao Y, Liu M, Li T, Huang F, Tang T, et al. (2013) A meta-analysis comparing the results of cervical disc arthroplasty with anterior cervical discectomy and fusion (ACDF) for the treatment of symptomatic cervical disc disease. J Bone Joint Surg Am 95: 555-561.

13. Cepoiu-Martin M, Faris $P$, Lorenzetti $D$, Prefontaine $E$, Noseworthy $T$, et al (2011) Artificial cervical disc arthroplasty: a systematic review. Spine (Phila Pa 1976) 36: E1623-1633.

14. Kim HJ, Kelly MP, Ely CG, Riew KD, Dettori JR (2012) The risk of adjacentlevel ossification development after surgery in the cervical spine: are there factors that affect the risk? A systematic review. Spine 37: S65-S74.

15. Dehn T (2007) Degenerative disc disease: disc replacement. Ann R Coll Surg Engl 89: 6.

16. Lehman R, Bevevino AJ, Brewer DD, Skelly AC, Anderson PA (2012) A systematic review of cervical artificial disc replacement wear characteristics and durability. Evidence-Based Spine-Care Journal 3: 31-38.

17. Yu L, Song Y, Yang X, Lv C (2011) Systematic review and meta-analysis of randomized controlled trials: comparison of total disk replacement with anterior cervical decompression and fusion. Orthopedics 34: e651-e658.

18. Gebremariam L, Koes BW, Peul WC, Huisstede BM (2012) Evaluation of treatment effectiveness for the herniated cervical disc: a systematic review. Spine (Phila Pa 1976) 37: E109-118

19. Yin S, Yu X, Zhou S, Yin Z, Qiu Y (2013) Is cervical disc arthroplasty superio to fusion for treatment of symptomatic cervical disc disease? A meta-analysis. Clin Orthop Relat Res 471: 1904-1919.

20. Zechmeister I, Winkler R, Mad P (2011) Artificial total disc replacement versus fusion for the cervical spine: A systematic review. Eur Spine J 20: 177-184.

\section{Author Affiliation}

${ }^{1}$ Centre for Pain Research, Leeds Beckett University, Leeds, UK ${ }^{2}$ University Hospital of North Tees, Stockton-on-Tees, UK

Submit your next manuscript and get advantages of SciTechnol submissions

* 80 Journals

* 21 Day rapid review process

* 3000 Editorial team

* 5 Million reader

* More than 5000 facebook"

* Quality and quick review processing through Editorial Manager System

Submit your next manuscript at • www.scitechnol.com/submission 